\title{
The continuing relevance of Croslandite social democracy
}

\author{
Kevin Hickson
}

The aim of this chapter is to argue that as social democrats look for an alternative to the New Labour/Third Way approach, as they inevitably must do given the rather moderate nature of many areas of domestic policy since 1997 and given the current economic crisis (leaving aside the disastrous foreign policy adventures of the Blair years, notably of course Iraq), we could find a number of relevant ideas in the British social democratic tradition, specifically in the work of Tony Crosland (1918-77). This is not to argue that Crosland's work is directly or entirely relevant to the contemporary situation. Over fifty years have passed since he wrote his major work, The Future of Socialism (Crosland [1956] 1963) and over thirty since his last significant publication, Socialism Now (Crosland 1974). Indeed, the essence of his argument was the need to revise the meaning of socialism as circumstances changed. The period since Crosland's death has marked a period of significant challenge to the socialist position he outlined, both intellectually in the form of the New Right and in terms of economic and social changes both domestically and internationally. Any attempt to restate a Croslandite socialist position would need to take account of such changes. Moreover, this chapter is not an attempt to state what Crosland would think if he were alive today. Such a statement would be impossible, although some, for example Gordon Brown, have tried to make it (Brown 2006). There is simply no way of knowing what Crosland would make of the twelve years of New Labour government since 1997. However, this does not mean that we cannot relate the ideas contained in The Future of Socialism to the contemporary situation, as Mark Wickham-Jones has argued in a recent article. While this chapter cannot consider all of Wickham-Jones's arguments, we can at least say that Crosland's ideas contain a theoretical core, based around a clear conception of equality, which, contrary to Wickham-Jones, can be applied to contemporary politics (Wickham-Jones 2007). Instead, all that can be done is to outline Crosland's position and how he responded 
to his critics and then to suggest in what ways his ideas can be reapplied to the contemporary situation.

The chapter begins by outlining the main arguments contained in The Future of Socialism. These consist of first an account of the transformation of the British economy, which was followed by a discussion of socialist aims and finally an analysis of the policies most appropriate for their attainment. Of fundamental importance for the revisionist position was the distinction between values and policies, or ends and means as they were labelled. The chapter then goes on to discuss the criticisms made of Crosland's arguments. Of these, the intellectual challenge from the New Right was the most serious and we need to discuss how revisionists in the 1980s sought to defend social democracy in the face of this intellectual challenge. The chapter also discusses certain wider empirical developments, which some commentators have argued spell the death of social democracy. Finally, the chapter seeks to demonstrate the continuing relevance of core elements of Croslandite social democracy. Briefly, these are the primary emphasis on equality as a guide to social democratic policies and the need to take the issue of corporate ownership seriously once again in the face of economic developments which have moved rather contrary to the trends that Crosland identified in the 1950s. There is therefore a lot of ground to cover when we examine the continuing relevance of Croslandite social democracy and inevitably this will involve touching on some of these issues rather briefly. ${ }^{1}$

\section{Crosland's thesis}

The Future of Socialism constitutes the major statement of post-war social democracy in Britain. There were other theoretical contributions to British social democracy after 1951, most notably by Roy Jenkins and Douglas Jay, but none provided the synthesis that Crosland's text provided (Jenkins 1953; Jay 1962). The first section of The Future of Socialism concerned the transformation of the economy (Crosland 1963: 1-42). Here Crosland talked of a transfer of power away from the capitalist class. When Marx had outlined his arguments for socialism the economy was structured around small-scale ownership, primarily the new mills and factories of the industrial revolution. The owners constituted a powerful social class in the absence of a welfare state and with only limited government intervention in the economy and the lack of strong trade union movements. For Marx, the owners of the means of production determined the distribution of wealth and income. On this view, issues of distribution cannot be separated from the structure of production and so the only possibility of creating a fairer society is to foster conditions for a revolution in which private property ownership would be terminated. ${ }^{2}$ 
However, by the end of the nineteenth century, social democrats were beginning to revise these fundamental tenets of Marxism, notably with the publication of Eduard Bernstein's The Preconditions of Socialism (Bernstein [1899] 1993). This revisionist tradition was important to Crosland's intellectual development and he sought to provide a similar tract for British social democracy in post-war conditions. He drew on the ideas developed in the academic literature about the separation of ownership and control within industry and the so-called 'managerial revolution', in which a managerial elite had emerged divorced from the old capitalist class (Berle and Means 1932; Burnham 1942). Specifically, Crosland identified four recent trends within political economy. The first was the transfer of power away from owners to the state. This was partly due to the nationalisation programme of the post-war Labour Government, which nationalised mostly loss-making industries amounting to one-fifth of the economy. However, the decisive factor in the transfer of power away from owners to the state was the development of Keynesian economic techniques, which provided the state, so Crosland believed, with sufficient power to regulate the private sector of the economy and maintain full employment and the growth that was needed for the expansion of social services. The second transfer of power away from owners was to labour, especially in the form of the trade unions, which derived their powers partly from the new, postwar structure of industrial relations but largely from the condition of full employment. Third, Crosland believed that there had been a transfer of power from owners to managers. This was important for a number of reasons. Crosland believed that the dispersal of ownership to a larger shareholding class, something which was necessitated by the increase in the size of the corporate unit, had divorced ownership from control in industry and that control now rested with managers rather than the traditional capitalist class. Hence, those in control of industry were no longer constrained by the overarching need to maximise profit, but rather could consider a wider range of corporate responsibilities. Finally, Crosland stressed the ability of democratic processes to transform the nature of the economy and society. By forming democratic political parties, trade unions, and so forth the workers and their representatives had been able to reduce poverty and enlarge the state so that it could counteract the effects of capitalism, for example with the formation of the welfare state and the achievement of full employment. Hence, social democracy had disproved the Marxist thesis that socialist advance could not be realised within liberal democracies. Crosland went so far as to argue that such conditions were not only the temporary reality but would be more enduring phenomena, not least as the Conservative Party had been forced to adapt to the new conditions for electoral survival. In fact, Crosland argued that the economy was no longer 
capitalist in any way in which commentators from the nineteenth century would recognise (Crosland 1963: 42).

Having set out the changed conditions, Crosland then sought to redefine the meaning of socialism (Crosland 1963: 43-80). Crosland argued that there was not a single 'true' form of socialism. Instead it was possible to identify a range of distinctive positions from the history of socialism. There were twelve socialist doctrines identified by Crosland: the natural law tradition, Owenism, the labour theory of value, Christian socialism, Marxism, the theory of rent as unearned income, anti-commercialism, Fabianism, the Independent Labour Party tradition, welfare state/paternalism, syndicalism and guild socialism and finally the doctrine of planning. The significance of this categorisation of socialism was to highlight the core values of that doctrine. Here Crosland specified five such aspirations: a protest against material poverty; the promotion of social welfare; the pursuit of equality and the creation of a classless society; the formation of social solidarity and community and finally a protest against the inefficiencies of capitalism and in particular the creation of full employment. Of these five aspirations Crosland argued that the first and last were no longer relevant as primary poverty had been alleviated apart from a residual poverty in some sections of society and the transfer of power discussed above had created a more efficient economic system; full employment was by the 1950s well established and accepted as the principal aim of economic policy by both of the major parties. The fourth aim of promoting cooperation and a stronger sense of community Crosland said that he fully supported but not at the expense of personal liberty and indeed felt that this would not be a particularly significant objective for socialists at that stage since there was in any case a stronger sense of community than had existed in pre-war conditions. The major socialist objectives should therefore be welfare and equality. Of these the promotion of welfare was needed to eliminate the remaining cases of primary poverty and above all to improve public services. Crosland placed even greater emphasis on equality and here the discussion becomes more conceptual.

Discussion of equality as a political concept usually involves making a distinction between equality of opportunity and equality of outcome (income and wealth). In relation to this distinction Crosland formulated a complex notion of equality, which amounted to more than equality of opportunity but at the same time rejected complete equality of outcome as something undesirable and impractical. One consequence of this formulation has been some conceptual confusion. This is certainly true of accounts which have sought to criticise Crosland from the left, where the argument has been presented that all the Croslandite position amounted to was a demand for equality of opportunity (for instance Howell 1976: 193; Crick 
1960). This interpretation is rather surprising given that Crosland goes on to say that the goal of equality of opportunity, though desirable, is insufficient (Crosland 1963: 169). We therefore need to outline what Crosland meant by equality in more detail, not least as it is relevant when we come to discuss why Crosland's ideas ought to be of contemporary relevance.

First, Crosland certainly believed that equality of opportunity was desirable (Crosland 1963: 159-62). He thought that Britain in the 1950s was some way towards equality of opportunity but not as close as other countries such as the USA. The major obstacle to equality of opportunity, defined as the equal chance to compete for social positions, was twofold. First, the existence of a propertied, aristocratic class, upheld through nepotism and the top public schools, acted as a barrier to a true equality of opportunity. Second, the existence of social class divisions and wide inequalities of incomes and wealth acted as a further barrier to equal opportunity. Hence, the definition of equality of opportunity offered by Crosland was a radical one, requiring both lifelong opportunities rather than the one-off form of equality of opportunity that selective secondary schools represented. It would also require significant redistribution and the eradication of social class divisions. Equality of opportunity was therefore desirable, but in the final analysis, 'the limited goal [of equality of opportunity] is not, from a socialist point of view, enough' (Crosland 1963: 169).

Second, then, Crosland sought to place a concern for greater equality of outcome at the centre of the socialist agenda. Indeed, he argued explicitly that although the Labour government from 1945-51 had led to a transformation of capitalism it had not succeeded in introducing socialism since there was still too much inequality. Crosland argued that complete equality in income and wealth was not attractive and impossible and that it had never been a socialist aspiration (with the exception of George Bernard Shaw). However, this did not mean that material inequalities should be tolerated at the levels they were at in the 1950s. It would be difficult, with income tax rates at high levels, to do much by way of further redistribution of income without reducing incentives, but in Crosland's view what was more important was to redistribute wealth and to that end he proposed a range of wealth taxes (see Jackson 2005: 425-9). Moreover, equality could only be a reality in Britain if there was substantial reform to the education system. This would entail a reform of the public schools, in particular allowing for more free places (starting at 25 per cent and rising up to 100 per cent later on), and also a removal of educational selection, with comprehensive schools replacing the existing tri-partite structure of secondary education (grammar, technical and secondary modern schools), which Crosland believed did more than anything else to reinforce social class divisions (Crosland 1963: 188-207). In the 1960s, Crosland served as Secretary of 
State for Education, when he issued a circular that encouraged educational authorities to adopt the comprehensive model of secondary education (Crosland 1982; Jefferys 1999; Price 1999).

There are three further issues which need to be discussed before we move on to examine critical responses to Crosland. The first is the extent to which he presented an ethical argument in favour of equality. Crosland did make several arguments in favour of equality (Crosland 1963: 123-49). The first was the need to avoid social waste; that is, a system in which there were major obstacles to the realisation of equality of opportunity would result in the failure to make the most efficient use of human resources. Greater human talent to fulfil important roles in the economy would result from a more equal society. Second, Crosland argued that equality was desirable as it would overcome social resentment and create a more harmonious form of social relations. Finally, Crosland argued that equality was necessary for the attainment of social justice. People were unable to make best use of their natural endowments in a highly unequal society whereas others benefited disproportionately from the market. Hence, Crosland advocated the idea of the 'rent of ability', which suggested that there needed to be differential wage rates to allow for extra effort and skills for those who completed difficult work that was to the benefit of society, but at the same time did not just leave the extent of these differentials to be determined by the interplay of supply and demand in the free market. Such free-market conditions would on the contrary create unfairness in the distribution of incomes and wealth.

However, the difficulty here is that Crosland, apparently influenced by the ideas of A. J. Ayer (Ayer 1946) concerning the subjectivity of ethical arguments, stated that there was no objective way of determining between competing ethical standpoints (Vaizey 1983: 83). Hence, Crosland effectively suggested that the claims of social democrats against those of economic liberals could not be settled objectively. At the time he was writing, he did not see this as a particular problem, believing that free-market ideas were in any case marginal to public debate, which indeed they were at that time. However, this did place social democrats in a difficult position from the 1970s onwards when the free-market ideas of thinkers such as Hayek (Hayek 1960) directly attacked the central nostrums of social democracy such as equality, social justice and welfare rights. Hence, by the 1970 s social democracy had already been put on the intellectual back foot. We will address this issue below and examine how social democrats responded to this intellectual assault.

The second issue concerns Crosland's view of nationalisation. In making a rigid distinction between ends and means - socialist values and the policies used to realise those values - Crosland was seeking to downplay the 
importance of public ownership. This was no doubt in part for electoral reasons. The Labour Party was in opposition from 1951 and its electoral position deteriorated over the course of the decade. One reason for this, or so it was argued by some electoral analysts and party activists based around Hugh Gaitskell (party leader from 1955), was that nationalisation was losing the party considerable support. However, it was also the case, as has been demonstrated earlier in this chapter, that Crosland sought to provide a clear intellectual analysis of recent economic trends and to show what the most appropriate socialist policies should be in these conditions. He argued that reforms such as the imposition of wealth taxes and comprehensive schools were central to the attainment of equality but further nationalisation was not, due to the divorce between ownership and control in industry mentioned above. This is not to say that he did not see any role for public ownership, but rather to say that it was no longer a central objective for Crosland's socialism.

The final issue to mention in passing before moving on to the criticisms made of Crosland's thesis is that he moved from a very optimistic view of the future direction of British politics in the 1950s to adopting a more pessimistic tone by the end of his life. This was partly due to the onset of economic recession in the 1970s but was also due to his perception of the timidity and orthodoxy of Labour's economic policies in the 1960s, when the objective of increased economic growth was sacrificed in an attempt to preserve the value of the pound and in response to public expenditure cuts in 1975-76 under international pressure (for which see Crosland 1974; Hickson 2005).

\section{Criticisms and responses}

The first significant critique of Crosland's work came from the left. A number of writers in the 1950s and 1970s argued that Crosland had been wrong to argue that control in the economy had split from ownership and that, therefore, public ownership should remain central to socialism. This was true of a number of commentators on the left and others, like John Strachey, who in many other ways had revised their own positions significantly after 1945 (Barratt Brown 1958a, 1958b; Holland 1975; Strachey 1956a, 1956b). Crosland sought to rebut many of these arguments (Crosland 1962, 1974). However, since I have examined this debate in detail elsewhere (Beech and Hickson 2007), for the purposes of this chapter I propose to focus instead on the second significant critique of Croslandite social democracy, from the free-market right.

At the time of the publication of The Future of Socialism, the economic liberal position was marginal. The Institute of Economic Affairs had recently 
been established to fight a rearguard campaign in defence of economic liberalism. The resignation of the Treasury Ministers in January 1958 after failing to convince the Cabinet of the need for spending cuts if anything reinforced the Keynesian consensus. Even in the 1960s, Powellism was essentially a protest against the political establishment. It was only with the election of Margaret Thatcher as leader of the Conservative Party in 1975 that economic liberalism finally came to influence elite opinion. The most powerful part of the economic liberal critique of social democracy was the philosophical case put by Hayek. Space does not allow for a detailed examination of Hayek's arguments (see Hoover and Plant 1989; Barry 1987), but it is possible to list the main criticisms he made against social democracy. Hayek sought to reject the central objectives of social democracy. First, he argued that it was simply wrong to talk of social justice since this was a 'mirage'. Justice concerned only the intentional consequences of human action. Since people did not intend to harm others by making them unemployed, poor, and so on through the pursuit of their own interests in the market they could not be deemed to have acted unjustly. Moreover, Hayek added, the idea of a positive conception of liberty in which the state would provide through welfare provision the resources required to allow people to realise their objectives was a false definition of liberty; true liberty ought to be seen only as freedom from coercion. People were free so long as they were not intentionally coerced. The idea of equality was rejected by Hayek on the grounds that it was impossible to achieve. Since even social democrats had rejected the idea of complete equality of outcome there was in fact no coherent way of determining how resources should be redistributed. There was merely a set of competing principles of distribution with no way in a pluralistic society of deciding objectively between them. Finally, the idea of welfare rights was rejected on the grounds that they were resource dependent and since resources were limited there was no way of guaranteeing the claims of citizens in demanding welfare provision. These arguments, when combined with a range of economic theories such as monetarism, sought to restrict the freedom of government action in terms of economic policy that Keynesian theory had effectively provided, constituting a powerful intellectual challenge to the revisionist paradigm within social democracy.

Added to this theoretical critique of social democracy was an empirical one, which argued that social democracy had undermined economic efficiency. The argument was that the taxation and regulatory measures desired by social democrats to meet their social policy objectives had undermined economic growth, leading ultimately to the decline of the British economy since 1945. On this account, social democrats had failed to understand the nature of markets. This criticism from the New Right was in fact rather similar to the Marxist one mentioned above, namely 
that social democracy was flawed since it was not possible to achieve social democratic objectives within a capitalist economy. From the radical left the argument was made that a thoroughly socialist economic policy would have to be adopted, extending state control and nationalisation. For the right, the social democratic advance of the post-war years would need to be reversed, through policies such as privatisation, deregulation and flexible labour markets. The neo-liberal claim was that in turn this would achieve higher rates of economic growth and would therefore allow for the reduction of poverty. Specifically, it was argued that some of the new wealth created would 'trickle down' to the poor. The market was therefore argued to be a more effective method of reducing absolute poverty, even if more inequality would result from a free-market economic policy. These neo-liberal claims - both theoretical and empirical - will be examined in the final section. However, it is first important to consider a more recent criticism of social democracy.

In the 1990s critics of Croslandite social democracy added to these intellectual and economic challenges the argument that 'real world' changes had effectively brought about the 'death of social democracy'. A recent statement of this type has been made by Vernon Bogdanor, who has argued that the Premiership of Tony Blair and the idea of the 'Third Way' essentially marked the attempt by the left to come to terms with social democracy's demise (Bogdanor 2007). The death of social democracy was, he believes, due to several factors, all of which point to the impossibility of applying Crosland's ideas in contemporary conditions. The first was the inability of the central state to control the private sector of the economy after the reforms of the New Right, which significantly transferred powers from the public to the private sector. Second, there has been a dramatic transfer of power from the nation-state in the form of globalisation. Finally, there has been a transfer of power from the nation-state to sub-national government, most obviously in the form of legislative devolution to Scotland and Wales. Hence the central state, which was the main forum through which equality would be achieved for Crosland, has lost power in three directions: outwards, upwards and downwards. In such conditions, Bogdanor argues, there is very limited scope for the introduction of social democracy in Britain, where neo-liberal reforms went further than in many countries. There would therefore seem to be very little scope for a revival of a form of social democracy that is more radical than the one we have witnessed in the twelve years of New Labour government, which although marking some important moves away from Thatcherism (such as the minimum wage, New Deal, redistribution, higher levels of public spending on health and education, and so on), has also seen some important aspects of continuity with the policies and ideas of the previous Conservative administration (most notably the failure to reduce 
substantive inequalities and the continuing emphasis on the use of markets and the involvement of the private sector in public service delivery). If the above analysis is correct, then we may well be able to appreciate why, after a decade of a Labour administration, British public policy still displays elements of economic liberalism. It remains to be seen if a more radical, distinctively social democratic position is attainable.

\section{A future for social democracy}

In the remainder of the chapter, I wish to sketch out how a revised form of Crosland's socialism would look. We need to do three things here. The first is to outline what form a philosophical defence of social democracy against the economic liberal critique ought to take and then go on to apply these ideas to a number of policy issues that have arisen under New Labour. Second, we need to give a Croslandite response to the criticism of social democracy as undermining economic efficiency. Third, we must subject Bogdanor's 'death of social democracy' thesis to critical scrutiny.

Fortunately, the philosophical case for social democracy has been made already by a number of commentators in the 1980s, most significantly by Raymond Plant (Hoover and Plant 1989; Plant 1991, 1996). Plant has provided the most sophisticated counter-argument to Hayek. His ideas influenced a number of senior Labour Party figures in the 1980s, including Roy Hattersley, Bryan Gould and Giles Radice (Hattersley 1987; Gould 1985, 1989; Radice 1989). There are a number of detailed points that Plant makes against the economic liberals and here I will summarise them briefly in a way that responds directly to the points made above detailing Hayek's position.

First, the idea of justice should be seen as referring not just to intentional acts but also to foreseeable ones, hence the criminal offence of manslaughter, which was based directly on foreseeable but unintended consequences. Given that the rise of inequality was predicted by economic liberals -indeed it was deemed to be one of the desirable outcomes of free-market policies then these consequences could be deemed to be a matter of social justice even though they were not intended. Demands for higher welfare expenditure and so forth were a matter of justice as a response to the foreseeable consequences of free-market policies, which generated poverty, unemployment and inequality.

Second, the negative conception of liberty formulated by Hayek freedom defined as freedom from coercion - was erroneous because it failed to understand the nature of liberty. In asking the question what is liberty for, most people would reply that it was necessary in order to be able to do things. Freedom from coercion was therefore necessary, but only as a 
precondition for the exercise of liberty. The idea of freedom should be seen as much closer to the conception of liberty formulated by social liberals and social democrats, with the emphasis on possessing the ability to do things.

The third social democratic principle rejected by Hayek was that of equality. Again, Plant and others sought to defend the idea of equality, as without it the conception of poverty was meaningless. Poverty had to be seen as a relative condition, as it only made sense to determine if someone was in poverty if they were living below the level of income that meant they were unable to exercise the accepted ideas of citizenship in a given society. Poverty meant not just the lack of the means of life but also the lack of sufficient resources to become an active citizen.

Finally, Plant sought to defend the idea of welfare rights, arguing that since all rights were in fact dependent upon finite resources there was no categorical distinction between welfare rights and other forms of rights. Hayek and other economic liberals had been right to stress the competing claims that were made on the distribution of resources but instead of this meaning that the notion of welfare rights had to be rejected completely, Plant said that there was a need to reach a social consensus on what form the pattern of distribution should take.

There are, I think, two issues here which are important to the discussion of the contemporary relevance of Crosland's ideas. The first is the distinction between moral and mechanical reformers made by Peter Clarke (Clarke 1978). ${ }^{3}$ Moral reformers are those who work from the bottom up seeking to convert public opinion, while mechanical reformers are those who seek to work from the top down driving change through executive action and legislation. Crosland was a mechanical reformer in this sense, although as we have noted he did seek to provide a number of arguments in defence of greater equality. The point is that it was not enough to say that a belief in equality is ultimately subjective. When the intellectual and ethical challenge to social democracy came in the 1970s and 1980s in the form of economic liberalism sufficient numbers of people voted for the Conservative Party and social democrats found it difficult to provide an ethical defence of their position. Hence, it is necessary to make explicit the case for equality and to argue against economic liberalism in the clear belief that social democracy is ethically superior.

The second issue that is of direct relevance is that revisionists of the $1980 \mathrm{~s}$ such as Plant and Hattersley placed significant emphasis on equality, and defined it as something more than equality of opportunity. ${ }^{4}$ The definition of equality was one much more akin to that formulated by Crosland in The Future of Socialism and in fact is one that constitutes something which is ethically distinctive from equality of opportunity. This is the central value difference between traditional and modernising social democrats. In all 
accounts of those who have expressed sympathy for a modernised, New Labour-style social democracy, the idea of equality is one that is restricted to equality of opportunity, as Plant has made clear (Plant 1999). For traditional social democratic critics of New Labour this restriction of equality to equality of opportunity constitutes a fundamental value shift. Hence, Crosland's emphasis on the centrality of equality for social democrats comes to have particular significance when we examine the more contentious aspects of New Labour's domestic policy agenda.

Here a range of issues could be discussed and I will briefly mention only three: income tax, welfare reform and schools reform. In terms of income tax, New Labour refused for largely electoral reasons to pledge to increase the top rate of income tax or to introduce a new higher rate until forced to do so by the economic situation. This raises issues in terms of the ends-means distinction made by Crosland and other post-war revisionists. Crosland maintained that there was a rigid distinction between ends and the policies used to realise those ends. In some accounts of modernised social democracy income tax is therefore one of several means available to achieve redistribution. There has certainly been substantial redistribution of income since 1997, with increases in taxation falling mainly on the top 10 per cent of income earners and extra welfare expenditure going mainly to poorer pensioners and families with young children. However, at the same time the incomes of the richest have continued to increase. The result of this is that the gap between rich and poor remains broadly the same as the level it was in 1997 (Stewart 2007). If the gap between the rich and the poor is deemed to be important, as it was to Crosland and other social democrats until the advent of New Labour, then it would seem that income tax is the only viable strategy for creating a more equal and fair distribution of income. Hence, rather than being one means among many, income tax can better be regarded as an indispensable means for social democrats. The proposal to create a 50 per cent income tax rate for those earning over $£ 100,000$ per annum made by the Fabian Commission on Taxation and Citizenship should be seen as a necessary means for social democrats to create a fairer and more equal society (Fabian Society 2000). Similarly, the emphasis that Crosland placed on the redistribution of wealth should also lead us to think that New Labour has revised ends and not just means in its reluctance to drive through fiscal measures to redistribute wealth, the distribution of which is even more unequal than is the case with income.

The other areas mentioned above - welfare reform and schools reform - can be taken together since they both concern the most appropriate way to reduce inequality. The proposals of New Labour have been to extend choice in both welfare services - especially the National Health Service and in schools. Foundation hospitals, the attempt to create something akin 
to the internal markets created by the Conservatives in the NHS, and the creation of city academies and specialist schools are all attempts to create more choice for patients and parents. However, a concern expressed by traditional social democrats against some or all of these reforms is that they will reinforce the inequalities present in society more generally. This is not so much a matter of income and wealth inequality, at least not directly, as public services would still be provided free at the point of use. However, certain groups in society - what for convenience we could term the middle classes - would be better able to exercise the choices presented to them due to having a greater awareness of the options available and by being able to voice their preferences more effectively than others. In a recent attempt to justify such policies, Rajiv Prabhakar has argued that inequality is a feature of existing public services (Prabhakar 2006). This is no doubt the case and he has presented sufficient evidence to demonstrate this. However, the extension of market mechanisms, which underpin most recent reforms, would seem to egalitarians to be more not less likely to create further inequalities in public services and it is the responsibility of those who argue for such reforms to show how they would help to reduce inequality (for further discussion, see Chapter 8 in this book). Hence, Crosland's egalitarian emphasis is particularly relevant in terms of public services, where any reform must be assessed in terms of its impact on inequality.

Second, when we turn to the empirical argument presented by neoliberals - that a free-market policy framework could best increase the rate of economic growth and reduce absolute poverty through the 'trickle-down' effect - we can again see that it is possible to defend the social democratic position. First, neo-liberals claimed that overall economic growth would be higher under free-market policies. There is some truth in this in that economic growth in Britain was higher in the 1980s than in the 1970s. Indeed, this could hardly be otherwise given the poor condition of the British economy in the 1970s. However, economic growth was higher in the 1950s and 1960s than it was in the 1980s and therefore we can see that there is no direct relationship between social democracy, neoliberalism and the rate of economic growth. In the period 1962-72, the rate of growth of GDP was above 2 per cent. In the 1980s, it was under 2 per cent. The second empirical claim - that the market is more effective at reducing poverty levels is proven false when one looks at the increased level of poverty in Britain the 1980s. The average increase in the incomes of the poorest 10 per cent of the population was significantly higher in the postwar period than in the 1980s, whereas the proportion of those considered to be living below the poverty line increased substantially in the $1980 \mathrm{~s}$ (statistics in this paragraph are from Budge et al. 1998: 22-5; for further discussion, see Hoover and Plant 1989: 155-84). 
Third, we must consider the purported death of social democracy. As mentioned above, a recent articulation of this viewpoint has been made by Bogdanor, who stresses the ways in which power has shifted upwards, outwards and downwards leaving the central state effectively hollowed out and unsuitable as a mechanism for the introduction of social democracy. Certainly, the recent transfer of power away from the central state should not be simply ignored and does make the pursuit of social democracy more difficult. However, there are a number of points that can be made here. First, in terms of the transfer of power outwards from the state, it can be observed that the privatisations of the 1980s were accompanied with regulatory regimes and so it is possible to talk of a regulatory state in which central government retains substantial powers over the economy (Moran 2003). Moreover, privatisation, although initially popular in the 1980s, became more controversial in the 1990s and it may be possible to build a social consensus for limited re-nationalisation measures in cases such as the railways where very high levels of public sector investment have not necessarily resulted in improved performance. Equally, in areas such as public-private partnerships and private finance initiative schemes the claim made by New Labour to do what works can seem more doubtful now. Gordon Brown did talk of a "public interest test' in determining the level and form of private sector involvement and although nothing has been done to develop this, it would seem a particularly fruitful idea to build upon. The idea that power has been transferred upwards from the nation-state in the form of globalisation can also be questioned, since the statistics available are contentious and some commentators have doubted the extent to which the process undermines the ability of nation-states to at least influence the activities of large corporations (Hirst and Thompson 1999). Similarly, the transfer of powers downwards to sub-national government should not lead us to assume that the state lacks sufficient powers to introduce radical reforms from the centre. The experience of devolution in fact shows us that where legislative powers have been decentralised there has been more scope for the implementation of social democratic measures not less, as is the case in Wales and Scotland.

Hence two points can be made by way of conclusion - that Crosland's position is more relevant than may at first be thought and second that such a position allows for a more radical formulation of social democracy than the one we have witnessed in Britain since 1997. In terms of the ongoing relevance of Crosland's ideas, this essentially revolves around the definition of equality that he formulated and its centrality to the social democratic project. Equality ought to involve more than a commitment to equality of opportunity, even an extensive notion of equality of opportunity as we 
have witnessed with New Labour, since without the correction of unfair market outcomes at the top and the bottom of the income scale, social injustice will result. Similarly, without an overriding concern with equality, public services involving the heavy use of market mechanisms will result in injustice. In terms of the radicalism of Crosland's ideas in contemporary conditions we should perhaps not be surprised. Richard Crossman, Crosland's intellectual rival on the left of the Labour Party for much of the 1950s, was prepared to admit in private that Crosland's arguments were radical than many realised: 'They are diabolically and cunningly left wing and Nye (Bevan) should have been clever enough to think them up' (quoted in Jefferys 1999: 63). Indeed, Crosland did not just attack those on the left, but also criticised the moderates on the right of the Labour Party. As Susan Crosland has commented: 'His tough-mindedness made him impatient with the right's caution, its tendency to woolly-mindedness. In later years as many on the right became readier to compromise with existing social structures, his impatience bordered on hostility. He said he was an egalitarian and he meant it' (Crosland 1982: 71).

\section{Notes}

1 Crosland has been subject to a number of studies including those by Susan Crosland (1982), Kevin Jefferys (1999), David Reisman (1997a, 1997b), and the volumes edited by David Lipsey and Dick Leonard (1981) and Leonard (1999). The author has also written at more length on a number of the issues discussed in this chapter in Beech and Hickson (2007) and is grateful to Simon Griffiths and the editors of this volume for their comments on an earlier draft of this chapter.

2 This was the essence of his critique of the Gotha Programme formulated by the German social democrats. See Marx [1875] (1938).

3 A similar view of Crosland's social democracy was taken by David Marquand (1996).

4 For a recent account of Hattersley's thought on these issues and the influence of Plant on 1980s Labour Party revisionism, see Beech and Hickson (2007).

\section{References}

Ayer, A. J. (1946) Language, Truth and Logic (London: Gollancz).

Barratt Brown, M. (1958a) 'The insiders', Universities and Left Review, 3, winter.

Barratt Brown, M. (1958b) 'The controllers', Universities and Left Review, 5, autumn.

Barry, N. (1987) The New Right (London: Croom Helm).

Beech, M. and Hickson, K. (2007) Labour's Thinkers: the Intellectual Roots of Labour from Tawney to Gordon Brown (London: I.B. Tauris). 
Berle, A. and Means, G. (1932) The Modern Corporation and Private Property (New York: Macmillan).

Bernstein, E. [1899] (1993) The Preconditions of Socialism, ed. by H. Tudor (Cambridge: Cambridge University Press).

Bogdanor, V. (2007) 'Social democracy', in A. Seldon (ed.), Blair's Britain 19972007 (Cambridge: Cambridge University Press).

Brown, G. (2006) 'Foreword', in C. A. R. Crosland, The Future of Socialism (London: Constable).

Budge, I., Crewe, I., McKay, D. and Newton, K. (1998) The New British Politics (London: Pearson).

Burnham, J. (1942) The Managerial Revolution (London: Putman).

Clarke, P. (1978) Liberals and Social Democrats (Cambridge: Cambridge University Press).

Crick, B. (1960) 'Socialist literature in the 1960s', Political Quarterly, 31 (3).

Crosland, C. A. R. (1956) The Future of Socialism (London: Cape).

Crosland, C. A. R. (1962) The Conservative Enemy (London: Cape).

Crosland, C. A. R. (1963) The Future of Socialism (New York: Schocken).

Crosland, C. A. R. (1974) Socialism Now and Other Essays, ed. by D. Leonard (London: Cape).

Crosland, S. (1982) Tony Crosland (London: Cape).

Fabian Society (2000) Paying for Progress: a New Politics for Tax and Public Spending (London: Fabian Society).

Gould, B. (1985) Socialism and Freedom (Basingstoke: Macmillan).

Gould, B. (1989) A Future for Socialism (London: Cape).

Hattersley, R. (1987) Choose Freedom: the Future for Democratic Socialism (London: Joseph).

Hayek, F. A. (1960) The Constitution of Liberty (London: Routledge).

Hickson, K. (2005) The IMF Crisis of 1976 and British Politics (London: I.B. Tauris).

Hirst, P. and Thompson, G. (1999) Globalisation in Question (Cambridge: Polity).

Holland, S. (1975) The Socialist Challenge (London: Quartet).

Hoover, K. and Plant, R. (1989) Conservative Capitalism in Britain and the United States: a Critical Appraisal (London: Routledge).

Howell, D. (1976) British Social Democracy (London: Croom Helm).

Jackson, B. (2005) 'Revisionism reconsidered: "Property-owning democracy" and egalitarian strategy in post-war Britain', Twentieth Century British History, 16 (4).

Jay, D. (1962) Socialism and the New Society (London: Longmans).

Jefferys, K. (1999) Anthony Crosland: a New Biography (London: Cohen).

Jenkins, R. (1953) Pursuit of Progress (London: Heinemann).

Leonard, D. (ed.) (1999) Crosland and New Labour (Basingstoke: Macmillan).

Lipsey, D. and Leonard, D. (eds) (1981) The Socialist Agenda: Crosland's Legacy (London: Cape).

Lukes, S. (1977) 'Socialism and equality', in S. Lukes, Essays in Social Theory (Basingstoke: Macmillan). 
Marquand, D. (1996) 'Moralists and hedonists', in D. Marquand and A. Seldon (eds), The Ideas that Shaped Postwar Britain (London: Fontana).

Marx, K. ([1875] 1938) Critique of the Gotha Programme (London: Lawrence \& Wishart).

Moran, M. (2003) The British Regulatory State: Hyper-Modernism and HyperInnovation (Oxford: Oxford University Press).

Plant, R. (1991) Modern Political Thought (Oxford: Blackwell).

Plant, R. (1996) 'Social democracy', in D. Marquand and Seldon, A. (eds), The Ideas that Shaped Postwar Britain (London: Fontana).

Plant, R. (1999) 'Crosland, equality and New Labour', in D. Leonard (ed.), Crosland and New Labour (Basingstoke: Macmillan).

Prabhakar, R. (2006) Rethinking Public Services (Basingstoke: Palgrave).

Price, C. (1999) 'Education secretary', in D. Leonard (ed.), Crosland and New Labour (Basingstoke: Macmillan).

Radice, G. (1989) Revisionism: Labour's Path to Power (Basingstoke: Macmillan).

Reisman, D. (1997a) Anthony Crosland: the Mixed Economy (Basingstoke: Macmillan).

Reisman, D. (1997b) Crosland's Future: Opportunity and Outcome (Basingstoke: Macmillan).

Stewart, K. (2007) 'Equality and social justice', in A. Seldon (ed.), Blair's Britain 1997-2007 (Cambridge: Cambridge University Press).

Strachey, J. (1956a) Contemporary Capitalism (London: Gollancz).

Strachey, J. (1956b) 'The new revisionist', New Statesman and Nation, 6 October.

Vaizey, J. (1983) In Breach of Promise (London: Weidenfeld \& Nicolson).

Wickham-Jones, M. (2007) 'The Future of Socialism and New Labour: an appraisal', Political Quarterly, 78 (2). 